\title{
Chalkbrood (Ascosphaera aggregata) resistance in the leafcutting bee (Megachile rotundata) II. Random matings of resistant lines to wild type
}

\author{
WP Stephen *, BL Fichter \\ Department of Entomology, Oregon State University, Corvallis, OR 97331-2907, USA
}

(Received 20 April 1989; accepted 13 March 1990)

\begin{abstract}
Summary - Random matings between 3 lines of the leafcutting bee, Megachile rotundata (Fabr), selected for resistance to chalkbrood, Ascosphaera aggregata Skou, and equal numbers of the wild type resulted in an incidence of chalkbrood equal to or greater than that of the wild type. The data suggest that the trait is polygenic and readily disrupted by out-crossing. The near equal incidences of chalkbrood among female and male larvae of this haplodiploid species suggest there is no sex linkage or dosage effect. The pollen mass trait also appears to be genetically mediated, independent of disease resistance and derived along different genetic pathways in each population from which the original selections were made.
\end{abstract}

chalkbrood / resistance / leafcutting bee / Megachile rotundata / Ascosphaera

\section{INTRODUCTION}

In 1977, 29 straws each containing from 5-9 live larvae and no chalkbrood cadavers were selected from a population of leafcutting bees (Megachile rotundata (Fabr)) with over $35 \%$ chalkbrood (Stephen and Fichter, 1990). The premise of the ensuing studies was that, if the progeny of a single female were chalkbrood-free in such a heavily contaminated population, genetically-mediated disease resistance was perhaps being expressed. The original sample was split, expanded and selected at 2 isolated sites near Los Molinos
CA from 1978 to 1981 . Population subsamples challenged with chalkbrood spores after 4 (Line B) and 6 (Line A) generations resulted in a lower incidence of the disease than anticipated, a result which supported the premise of genetic resistance (Stephen and Fichter, 1990).

The criteria used for selection of the original stock were that each cell series (= soda straw) have more than 5 live larvae and no chalkbrood cadavers; each capped cell series was assumed to contain the progeny of a single female. As a consequence, none of the 29 straws contained dead larvae or pollen masses (ie pollen

* Correspondence and reprints 
provisions on which no egg had been laid, or the egg or early instar larva had died); it was postulated that the fungus could have been a factor in their premature death. Pollen masses are a major mortality component of leafcutting bees in the Pacific Northwest and in some areas the incidence approaches that of chalkbrood. During the 4 years of selection and challenge of the selected lines, pollen masses never exceeded $4.4 \%$ suggesting that this character may also be genetically influenced, either linked to, or independent of, the disease component (Stephen and Fichter, 1990).

In the following studies, each of 3 lines of leafcutting bees selected for disease resistance was randomly mated with Adrian, OR wild type (WT) and the progeny evaluated for disease and pollen mass incidence. Our objective was to ascertain the type of genetic control of resistance in the selected lines and to determine if such selections were of potential practical application.

\section{MATERIAL AND METHODS}

\section{Oregon stock}

The details of selection, expansion and analysis of 2 lines (Lines A \& B) from the Adrian OR population are provided in the companion paper (Stephen and Fichter, 1990). Subsequently, material was taken from the same population for random mating studies and is designated as the Adrian OR wild type (Adrian WT).

\section{Merced stock}

Using the same criteria as outlined above, a second selection was made from a $M$ rotundata population near Merced, CA in 1978 (Merced WT). This population had been in continuous culture in that area since 1965. No record of the 1st occurrence of chalkbrood in those populations exists but it was reported to be severe in 1975. In July 1978, 2 cartons of new, $14 \mathrm{~cm}$ long, brown paper soda straws were placed at the Merced site as trap-nests. Capped straws were removed for $\mathrm{X}$-ray analysis and by the end of the 1978 season 7 straws, each containing from 7-14 live larvae and no chalkbrood, were selected for challenging, selection and expansion at a site north of Corning CA (Select Line C).

\section{Study Sites}

All selected lines of leafcutting bees were expanded, challenged and randomly mated (backcrossed) at isolated sites near Los Molinos, Corning and Gerber, CA. Details of site selection are provided in Stephen and Fichter (1990).

\section{Expansion and selection}

All lines were propagated in $9 \mathrm{~cm}$ long $X 5.5 \mathrm{~mm}$ diameter brown, paper soda straws. All other methods are as described in Stephen and Fichter (1990).

\section{EXPERIMENTAL PROCEDURES}

\section{Experiment I}

This experiment was performed to determine the effect of random mating chalkbrood-resistant Select Line B with equal numbers of Adrian WT on disease and pollen mass incidence. Nineteen straws containing 114 live pupae of the 4th generation of selected Line $B$, along with 76 straws containing 111 live pupae of the 1978 generation of Adrian WT, were divided into approximately equal parts and transferred to 2 cartons of new, brown-paper soda straws. Cell series from both sources were mixed haphazardly among new paper soda straws in each carton and the cartons were placed in 2 small isolated field domiciles near Gerber, CA after first male emergence had begun (July 23, 1980). 
Females prefer to renest in tunnels from which emergence has recently occurred, presumably because of an aggregating pheromone liberated at emergence. While emerging from and renesting in contaminated straws, bees remove much of the refuse and disease inoculum. To maximize the possibility of reinoculating straws in each carton, each was fixed at an angle of $\mathbf{4 5}$ degrees up from horizontal. Bees were permitted to emerge, mate randomly and renest for $10 \mathrm{~d}$, at which time all straws which contained nuclei of selected and wild type cells were removed and destroyed so as not to bias the analysis. Filled capped straws were colorcoded on August 11 and August 31, left in situ for 2 wks for completion of larval development and then removed for X-ray analysis (Stephen and Undurraga, 1976). Controls of each parental population were established at isolated sites near Los Motinos, CA. All capped straws from each population were evaluated for live larvae, chalkbrood and pollen masses.

\section{Experiment /I}

This experiment was performed to determine the effect of random mating of a chalkbrood resistant line of Megachile rotundata from Merced CA (Select Line C) with equal numbers of Adrian WT on disease and pollen mass incidence. The Merced population (Line C) was expanded, challenged and selected for chalkbrood resistance during 1979 at an isolated site near Corning CA (table I). In the spring of 1980, 18 straws of the 4th expansion generation of selected Line C containing 102 live larvae, along with 64 straws from the 1979 Adrian WT population containing 104 live larvae were divided and half of each were mixed haphazardly in 2 cartons of new, brown paper soda straws. Methods described in Experiment 1 were followed. Capped straws were color-coded at 2-wk intervals and straws removed for analysis 2 wks following painting. All straws which contained nu-

Table I. Random matings of resistant line B of M rotundata with Adrian WT (Los Molinos, CA 1979).

* Total is less than $100 \%$ as cells parasitized or with dead larvae are not included.

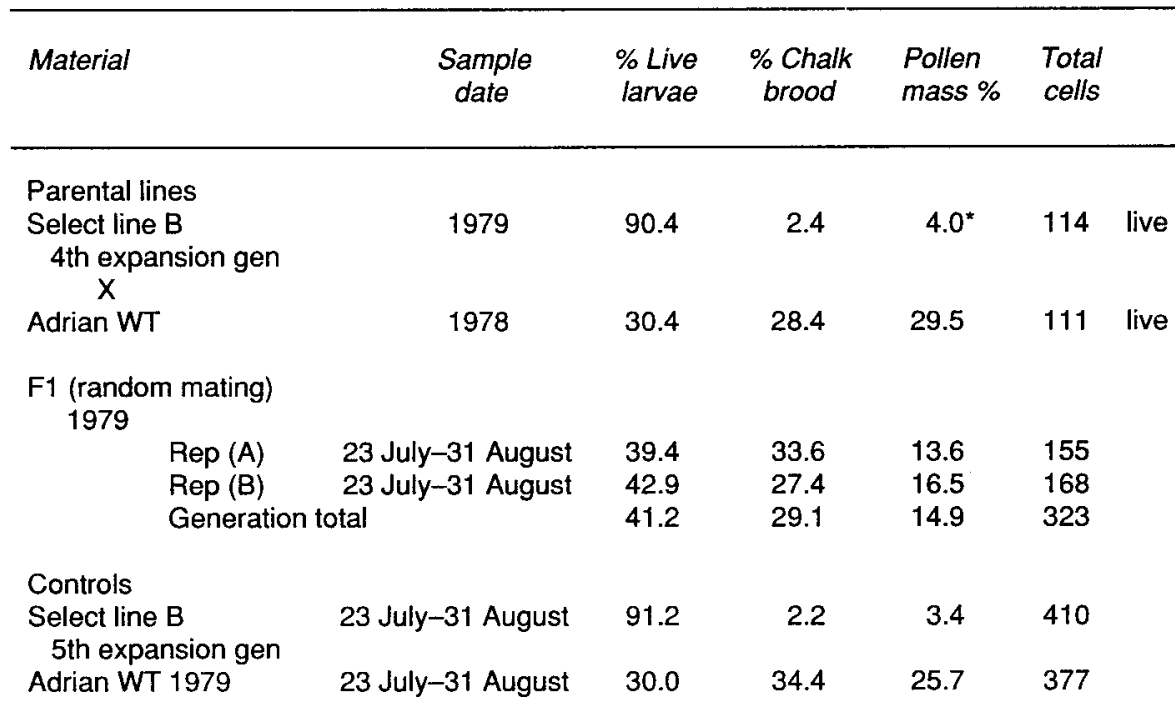


clei of the selected Line $C$ and Adrian WT cells were removed prior to analysis. Controls of Line C and Adrian WT were established at isolated sites near Corning and Gerber, CA, respectively. All capped straws were analyzed for incidences of live larvae, chalkbrood and pollen masses.

\section{Experiment III}

This experiment was performed to determine the effect of random mating of chalkbroodresistant selected Line $A$ with equal numbers of Adrian WT on disease and pollen mass incidence. In spring 1981, 30 straws of the 8th expansion generation of Line A containing 249 live larvae and 141 straws of overwintering 1980 Adrian WT containing 252 live larvae, were divided into 3 approximately equal groups, and arranged haphazardly among new, brown paper soda straws in each of the 3 cartons. Each carton was isolated on June 14 at sites near Los Molinos, CA. Each was separated by at least $0.5 \mathrm{~km}$ from the others and oriented and managed as described in exp I. Capped straws were color-coded at the end of the 2nd and 3rd wk of nesting activity. The experiment was terminated on July 8, 1981 because of bee kill resulting from pesticide drift from an adjacent orchard. Straws containing the nuclei of cells from Line $A$ and Adrian WT were not included in the analysis. Controls of Line A and Adrian WT were established in isolation near Los Molinos and Gerber, CA, respectively. All capped straws from each population were $X$-rayed and incidences of live larvae, chalkbrood and pollen masses determined.

\section{Experiment IV}

This experiment was carried out to determine through random mating of the $F_{1}$ of $\exp$ III, if the characters for chalkbrood resistance segregate as simple recessive alleles. The 98 capped straws from exp III containing 1 or more chalkbrood cadavers were incubated at $30^{\circ} \mathrm{C}$ until the 1st males emerged (July 22). Approximately equal numbers of straws were placed in each of the 2 cartons with new straws and returned to the field for emergence, mating and renesting.
Bees of the $F_{1}$ were permitted to mate randomly and reproduce until August 22 when the experiment was terminated. Cartons were maintained in the field until September 10 to permit larvae of the $F_{2}$ to mature. All capped straws were $X$ rayed and evaluated for live larvae, chalkbrood and pollen masses.

\section{RESULTS}

\section{Experiment I}

The 63 capped straws collected from the 2 randomly mated populations contained a total of 323 cells among which the incidence of chalkbrood approximated that of the Adrian WT parents (29.1 vs $28.4 \%$ ) and that of live larvae and pollen masses was intermediate between the 2 parental lines (table II). Thirteen of the 63 straws contained no chalkbrood cadavers and had an incidence of pollen masses nearly identical to that of the selected Line B (table III - exp I). If the females of this species mate only once and if non-assortative mating did occur between the selected and WT lines, then we would expect $25 \%$ of the cell series to be chalkbrood-free. Observations indicate that $20.6 \%$ of the cell series were chalkbrood-free, less than theoretical expectations if the selected line were completely resistant to the disease. Except for a slight increase in the incidence of chalkbrood in the Adrian WT population, control populations of selected and WT populations closely approximated parental lines in incidence of live larvae, chalkbrood and pollen masses (table II).

\section{Experiment II}

The Merced WT population from which selections were made was characterized by a higher incidence of chalkbrood (42.5 vs 
Table II. Selection of Line C (Merced, CA) for Resistance to Chalkbrood (1978 - 1979) and Random Matings of Selected Line With Adrian WT (1980).

* Total is less than $100 \%$ as cells parasitized or with dead larvae are not included.

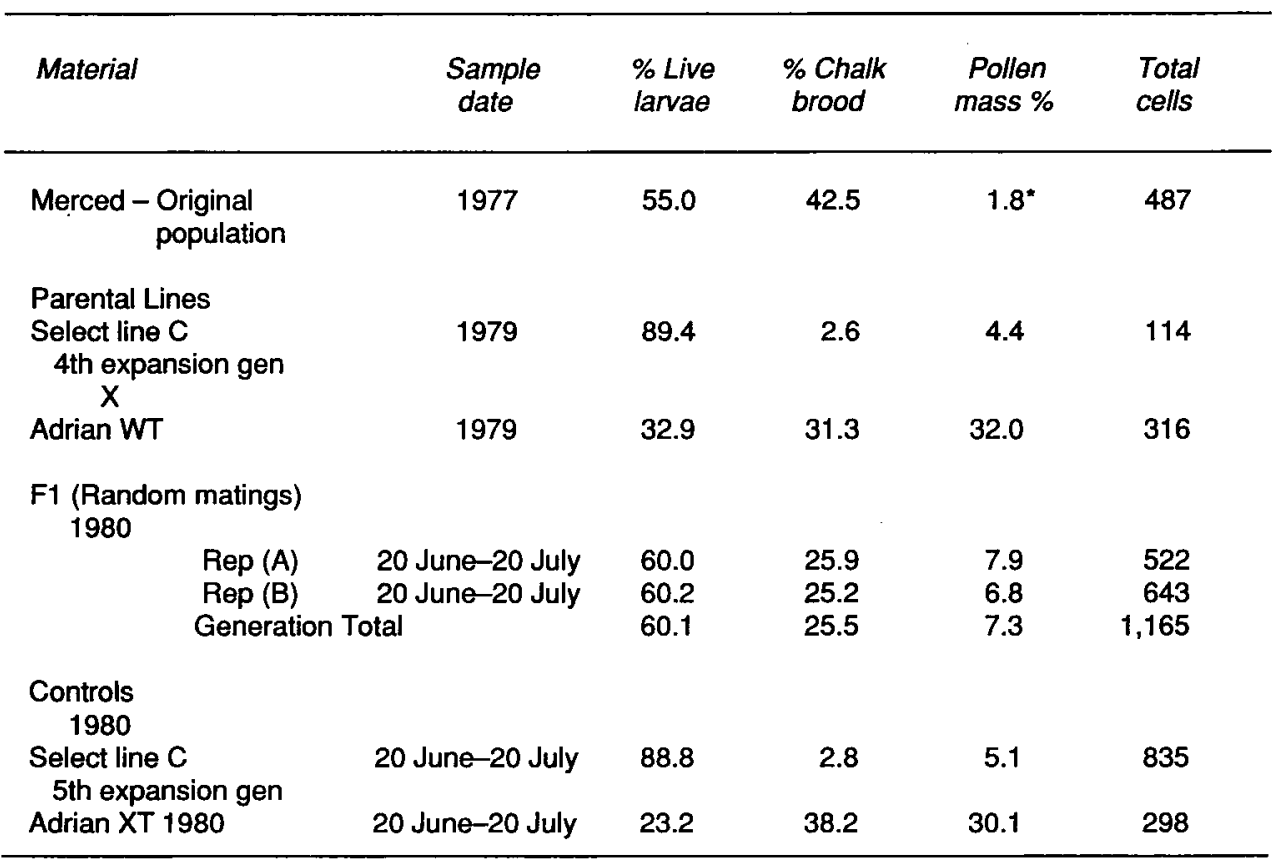

Table III. Random matings of selected line A with Adrian WT of M rotundata (Los Molinos, CA 1981).

* Total is less than $100 \%$ as cells parasitized and with dead larvae are not included.

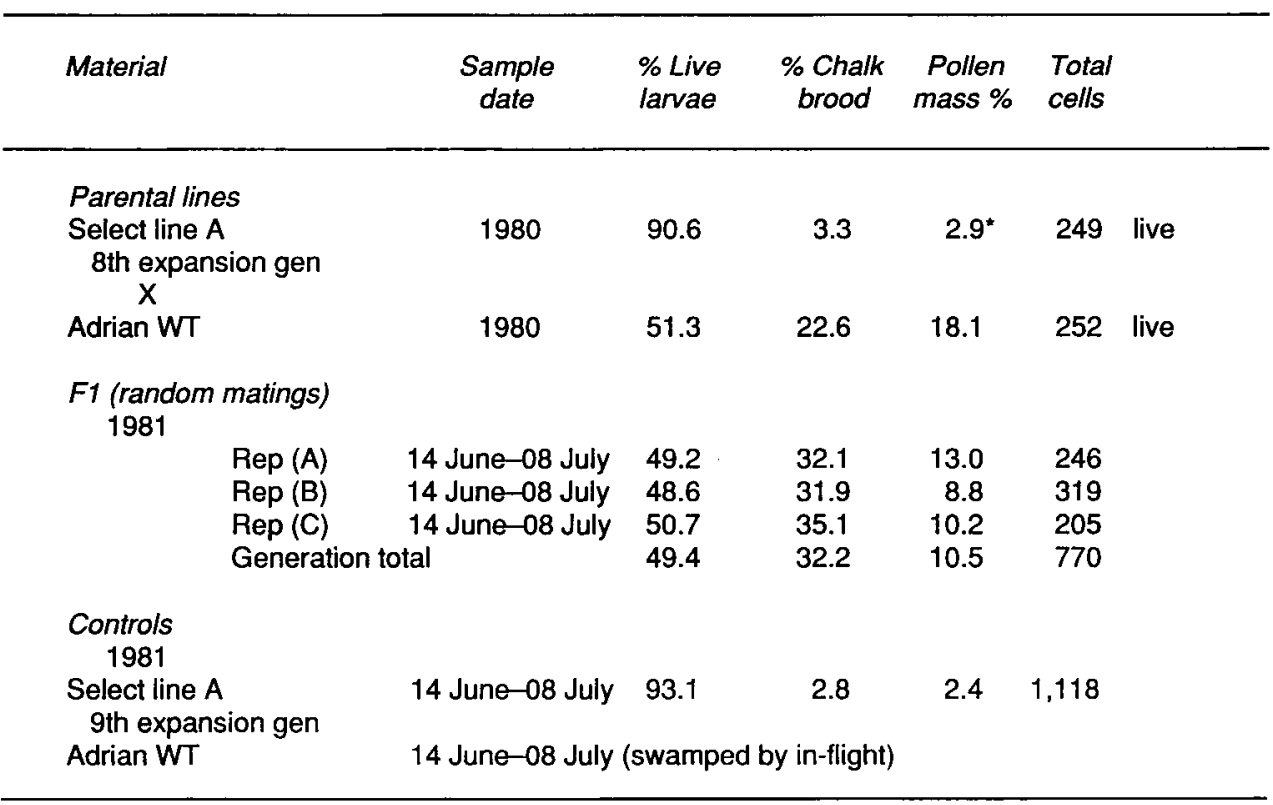


$31.3 \%)$ and a much lower incidence of pollen masses ( 1.8 vs $32.0 \%$ ) (table I, Original Population, 1977) than that of the Adrian WT 1979 (table I). Chalkbrood among the progeny of the random mating trial $\left(F_{1}\right.$ 1980) was slightly lower than that of the wild type (25.5 vs $31.3 \%$ ), the live larvae intermediate between the 2 parental lines and the pollen mass incidence low, comparable to that of the selected line $C(7.3$ vs $4.4 \%$ ) (table I). Approximately $20 \%$ of the capped straws of the random mating tests were chalkbrood free, fewer than expected from non-assortative mating among the 2 lines (table III, Exp II). Except for an increase in chalkbrood and decline in percent live larvae in Adrian WT, controls of each parental population were similar to the parental lines.

\section{Experiment III}

Cell production was approximately $50 \%$ of that anticipated because of the death of the adults exposed to pesticide drift. Random matings of the 8th expansion generation of Select Line A with the Adrian WT yielded progeny with chalkbrood well above that of the WT (32.2 vs $22.6 \%$ ), the incidence of pollen masses intermediate between those of the parental lines, and, approximately the same percent of live larvae as the WT (49.4 vs 51.3\%) (table IV, $F_{1}$ Random Matings). Control Line $A$ approximated the parental Line $A$ in percent live larvae, chalkbrood and pollen masses. The Adrian WT control was swamped by a massive in-flight of bees during the 1st wk after establishment and no data were recoverable. Thirty-six (25.7\%) of the 140 capped straws contained no chalkbrood cadavers (table III, Exp III).

\section{Experiment IV}

Both the percent live larvae (43.6 vs $36.4 \%$ ) and the pollen masses (18.2 vs $13.2 \%$ ) were higher among the progeny of the $F_{2}$ than the $F_{1}$; the incidence of chalkbrood fell slightly in the $F_{2}$ (37.5 vs $44.7 \%$ ) (table V). Of the 187 capped straws, 182 contained cells with from $1-6$ chalkbrood cadavers and only 2 (with a total of 6 cells) were disease-free (table III, Exp IV).

\section{DISCUSSION}

The data provide no evidence of dominant or semi-dominant alleles involved in disease resistance in the populations exam-

Table IV. F2 of cell series of F1 (experiment III) containing chalkbrood cadavers (Los Molinos, CA 1981).

* All capped straws (98) from Experiment III which contained one or more chalkbrood cadavers.

** Total is less than $100 \%$ as cells parasitized and with dead larvae are not included.

\begin{tabular}{|c|c|c|c|c|c|}
\hline Material & $\begin{array}{l}\text { Sample } \\
\text { date }\end{array}$ & $\begin{array}{l}\text { \% Live } \\
\text { larvae }\end{array}$ & $\begin{array}{c}\text { \% Chalk } \\
\text { brood }\end{array}$ & $\begin{array}{l}\text { Pollen } \\
\text { mass \% }\end{array}$ & $\begin{array}{l}\text { Total } \\
\text { cells }\end{array}$ \\
\hline $\begin{array}{l}\text { F1 cell series } \\
\text { with chalkbrood }\end{array}$ & 08 July & 36.4 & 44.7 & $13.2^{* *}$ & 555 \\
\hline $\mathrm{F} 2$ & 20 August & 43.6 & 37.5 & 18.2 & 879 \\
\hline
\end{tabular}


Table V. Frequencies and contents of straws from random mating tests having no chalkbrood cadavers.

* Expectations if females mate once and mating is non-assortative. ** If resistance is a simple recessive, expect $8.3 \%$.

\begin{tabular}{|c|c|c|c|c|c|c|c|c|}
\hline \multirow[b]{2}{*}{ Data source } & & \multicolumn{2}{|c|}{$\begin{array}{c}\text { Straws with } \\
\text { No chalkb }\end{array}$} & \multirow{2}{*}{$\begin{array}{c}\% \\
\text { Live } \\
\text { larvae }\end{array}$} & \multirow{2}{*}{$\begin{array}{c}\% \\
\text { Pollen } \\
\text { mass }\end{array}$} & \multirow{2}{*}{$\begin{array}{l}\text { Total } \\
\text { cells }\end{array}$} & \multicolumn{2}{|c|}{$\begin{array}{l}\text { Expected } \\
\text { straws w } \\
\text { No chlkb }\end{array}$} \\
\hline & & no & $\%$ & & & & No * & $\%$ \\
\hline Experiment 1 & $\mathrm{~F} 1$ & 13 & 20.6 & 89.7 & 2.9 & 68 & 15.3 & 25 \\
\hline Experiment 2 & F1 & 40 & 19.9 & 90.4 & 3.8 & 240 & 50.3 & 25 \\
\hline Experiment 3 & $F 1$ & 36 & 26.9 & 82.8 & 3.7 & 215 & 33.5 & 25 \\
\hline Experiment 4 & $\mathrm{~F} 2$ & 2 & 1.1 & 83.3 & 16.7 & 6 & 15.3 & ** \\
\hline
\end{tabular}

ined. In random matings of each resistant line with Adrian WT, the incidence of chalkbrood among the progeny equalled or exceeded that of the WT. Further, there was no evidence of simple character segregation in the $F_{2}$ (table $V$ ). This strongly suggests that disease resistance in these populations is polygenic and the selected trait is readily disrupted on out-crossing.

There does not appear to be any evidence of a dosage response or sex linkage in the resistance character in this haplodiploid species. For example, of the 140 straws capped in Exp III, 98 contained one or more chalkbrood cadavers and of these 59 contained at least 6 cells. There is a very high probability in a series of 6 or more cells that the upper 3 cells contain haploid males and the bottom 2 diploid females (Stephen, 1962; Klostermeyer and Gerber, 1969). If the character for resistance were a simple recessive then major differences in the position of the chalkbrood cadavers in the series would reflect sex linkage and/or dosage effect. The analysis of the 59 chalkbrood-containing capped straws with 6 or more cells showed a slightly higher incidence of cadavers among the first-formed (diploid female) than the last formed cells of each straw (haploid males) (fig 1), indicating that neither sex linkage or dosage effects were factors in resistance. This supports extensive data taken on the in-tunnel position of cadavers in the Adrian WT population (Fichter and Stephen unpublished). It is possible that this observed bias is a reflection of a gradual diminution over time in the body surface spore-load carried by the contaminated nesting female with greater inoculum loads scraped from the body at the time construction of the first cells (Stephen and Fichter, unpublished).

Resistance to chalkbrood in the leafcutting bee appears to be present in all bee populations. The evidence from spore inoculum challenges of selected lines in the companion paper (Stephen and Fichter, 1990) supports our more recent laboratory data on inoculum feeding to developing bee larvae (Stephen and Fichter, unpublished). Although $\mathrm{LD}_{50}$ 's were obtained by feeding larvae with 500-1000 spores, rarely have we been able to induce $80 \%$ mortality from chalkbrood regardless of the amount of inoculum fed (up to $10^{7}$ spores) or the instar to which the inoculum was administered (Fichter and Stephen, unpublished). Field observations are in accordance with these laboratory data as chalkbrood incidences of over $50 \%$ are rare even in the most highly infected natu- 


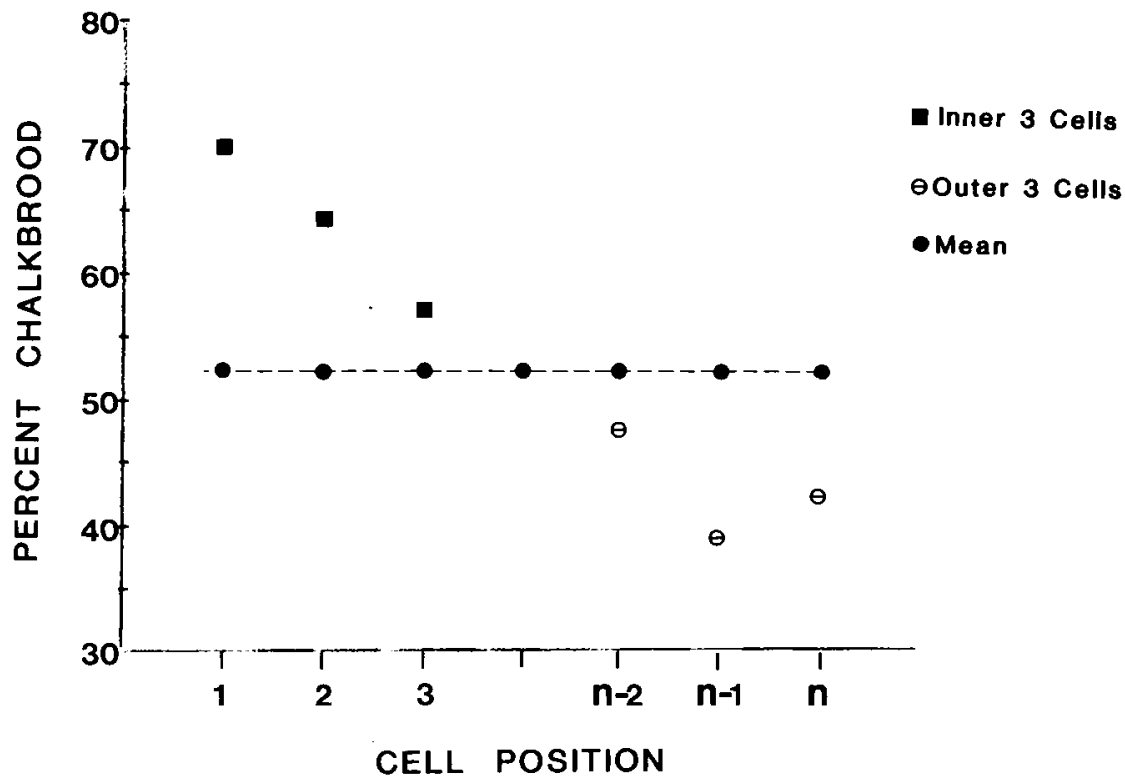

Fig 1. Incidence of chalkbrood in 59 cell series of Megachile rotundata with 6 or more cells. Cells in each series are numbered from 1 (innermost cell) to $n$ (outermost cell).

rally occurring populations of the leafcutting bee (Stephen, unpublished).

It was noted in the accompanying paper (Stephen and Fichter, 1990) that in the original selections from Adrian WT stock we had concomitantly selected for 2 characteristics : all live larvae, and, therefore, an absence of pollen masses. The incidence of pollen masses through 4 years of selection and expansion in all selected lines derived from the Adrian WT remained very low even though no direct selection was made for this character. Evidence presented in the previous paper suggested that both chalkbrood resistance and pollen mass frequency may be amenable to selection, either linked to, or independent of, each other. Random mating studies suggest that the pollen mass characteristic may also be under polygenic control, independent of that for disease resistance. In both random matings involving the selected lines derived from Adrian WT (Line $A$ and $B$ ) with the Adrian WT, the incidence of chalkbrood in the F1 exceeded that of the WT, whereas that of pollen masses was intermediate between those of the selected and WT populations. However, in the Merced WT 1972 population, the frequency of polien masses was very low $(1.8 \%)$ even though chalkbrood was higher than in the Adrian WT (table I). In selected Line $C$ (Merced) $X$ Adrian WT random matings, chalkbrood in the $F_{1}$ was slightly less than in the Adrian WT (25.6 vs $31.3 \%$ ) but pollen masses essentially remain those of the selected line (7.3 vs $4.4 \%$ ). That is, disease resistance collapsed as a result of outcrossing, but the trait for low pollen masses appeared to be unaffected. These data suggest that the 
pollen mass trait may be derived along different genetic pathways in each population from which the original selections were made.

Data presented in table III conform with non-assortative random mating expectations among equal numbers of resistant and susceptible individuals in a species in which females mate once. As each capped straw contains the progeny of a single female, we should expect $25 \%$ of the straws to be the result of resistant $x$ resistant parents and to be chalkbrood-free. However, chalkbrood resistance is not complete in the parental selected lines in any of the 3 experiments so that the number of observed chalkbrood-free cell series should be lower than the expected (25\%) - it is actually higher in exp III (table IV). This conformity with the above expectations is even more surprising because the premise on which these expectations are based (ie non-assortative mating among females which mate only once) are themselves open to question. In scores of observations made on paired virgin males and virgin females of Megachile rotundata in petri dishes, non-assortative mating did not appear to be the norm, and several females were observed to mate more than once (Stephen, unpublished). It may be that the stress imposed by long confinement of the bees to an arena in which flight and male avoidance are impossible is sufficient to invalidate any conclusions on mating behavior in this species. Unfortunately field observations and tagging have proven impractical.

Selection for a wide variety of characteristics can be effected in this highly variable species. In addition to these studies, the selection of obligatory univoltine lines has been reported (GH Rank, pers comm, $P$ Pankiw, pers comm). However, with current patterns of commerce, only those traits under the control of a dominant or semi-dominant allele can avoid being swamped by infusion from the extremely large propagated and/or "endemic" populations already resident in areas into which such selections are introduced.

\section{ACKNOWLEDGMENTS}

Technical Paper No. 9066 Oregon Agricultural Experiment Station. Supported in part by USDA ARS Cooperative Agreement No 58-9AHZ-3730 .

Résumé - Résistance au couvain plâtré (Ascosphaera aggregata) chez la mégachile (Megachile rotundata). II Accouplements au hasard de lignées résistantes avec le type sauvage. On a fait s'accoupler au hasard 3 lignées de Megachile rotundata (Fabr) sélectionnées pour leur résistance au couvain plâtré (Ascosphaera aggregata Skou) (2 de l'Orégon OR et une de Californie CA) avec un nombre égal d'individus du type sauvage de l'Oregon (Adrian WT). Dans un premier test, les adultes de la $5^{\mathrm{e}}$ génération issus de 19 pailles d'une lignée résistante ont pu s'accoupler au hasard avec un nombre égal de mégachiles issues de 76 pailles du type sauvage. Pour chaque lignée, les témoins ont été élevés en situation d'isolement. Le couvain plâtré a été plus fréquent chez les $F_{1}$ que chez le témoin du type sauvage, mais le nombre de masses polliniques a été intermédiaire. Lors d'un autre test portant sur des insectes de la $10^{e}$ génération, choisis pour leur résistance à la maladie, les adultes ont pu s'accoupler au hasard avec le même nombre d'adultes du type sauvage. Là encore la fréquence du couvain plâtré été plus élevée chez les $F_{1}$ que chez le témoin du type sauvage et la fréquence des masses polliniques intermédiaire entre les fréquences extrêmes des lignées parentales. Les descendants $F_{1}$ de chaque accouplement au hasard ont présenté une fréquence de couvain plâtré égale ou supérieure à celle 
du type sauvage, prouvant que le caractère de résistance est polygénique, non lié au sexe, et qu'il disparait facilement par outcrossing. Les données sont conformes aux prévisions de l'accouplement au hasard d'un nombre égal d'individus résistants et d'individus sensibles chez une espèce qui pratique l'accouplement unique : $25 \%$ environ des pailles contenaient des séries de cellules indemnes $(R \times R)$. Les cellules issues des accouplements au hasard des 2 lignées OR sélectionnées avec les lignées de type sauvage ont eu une fréquence de masses polliniques intermédiaire entre celle des fréquences extrêmes des lignées parentales. Dans les accouplements au hasard de la lignée CA sélectionnée avec le type sauvage, les pourcentages de masses polliniques ont été comparables à ceux des parents sélectionnés, bien que la fréquence du couvain plâtré soit celle du type sauvage. Ces résultats confirment notre affirmation selon laquelle le caractère masse pollinique est, génétiquement déterminé, indépendant de la résistance à la maladie, et issu de voies génétiques différentes dans chacune des populations à partir desquelles les sélections ont été faites.

\section{Megachile rotundata / Ascosphaera / couvain plâtré / résistance}

\section{Zusammenfassung - Kalkbrut- (Ascos-} phaera aggregata) Resistenz bei der Blattschneidebiene (Megachile rotundata). II. Zufallspaarung der resistenten Linien mit dem Wildtyp. Drei Linien der Blattschneidebiene (Megachile rotundata Fabr), die auf Resistenz gegen Kalkbrut (Ascosphaera aggregata Skou) gezüchtet waren, wurden mit dem Adrian-(Oregon)Wildtyp zufällig gepaart. Im ersten Versuch wurden Adulte der fünften Generation aus 19 Trinkhalmen einer Kalkbrut-resistenten Linie mit gleicher Anzahl Wildtypbienen aus 76 Trinkhalmen zufällig gepaart. Die Kontrollen wurden isoliert gehalten. Die Kalkbrut war in der $F_{1}$ stärker vertreten als bei den Wiltypkontrollen, die Pollenmenge war intermediär. In einem zweiten Versuch wurden Adulte der 10. Generation einer Kalkbrut-resistenten Linie mit WildtypAdulten zufällig gepaart. Auch hier war der Kalkbrutbefall größer als bei den Wildtypkontrollen und die Pollenmenge intermediär. Die $F_{1}$ aller dieser Zufallspaarungen zeigte einen Kalkbrutbefall, der gleich oder größer war als beim Wildtyp, was darauf hinweist, daß die Resistenzeigenschaft polygen und nicht geschlechtsgebunden ist und durch Auskreuzung sofort verschwindet. Das Ergebnis entspricht der Annahme von Zufallspaarung zwischen gleichen Anzahlen an resistenten und anfälligen Individuen einer Art mit Einfachpaarung: ca. $25 \%$ der Trinkhalme enthielten Zellserien ohne Befall (RxR). Die Zellen aus den Zufallspaarungen zwischen selektierten Oregon-Linien und Wildtyplinien zeigten intermediäre Mengen an Pollen. Bei Zufallspaarungen zwischen selektierten Linien aus Californien und dem Wildtyp entsprach die Pollenmenge im wesentlichen derjenigen aus den selektierten Linien, während der Kalkbrutbefall dem des Wildtyps entsprach. Dies unterstützt unsere Annahme, daß die Pollenmenge genetisch bestimmt ist, unabhängig von der Krankheitsresistenz vererbt wird und sich in den verschiedenen Population auf unterschiedlichen genetischen Wegen entwickelt hat. 
Megaliche rotundata / Ascophaera I Kalkbrut / Resistenz

\section{REFERENCES}

Klostermeyer EC, Gerber HS (1969) Nesting behavior of Megachile rotundata monitored with an event recorder. Ann Entomol Soc Am $62,1321-1325$
Stephen WP (1962) Propagation of the leafcutter bee for alfalia seed production. Oreg Agric Exp Stn Stn Bull 586, 16

Stephen WP, Fichter BL (1990) Chalkbrood (Ascosphaera aggregata Skou) resistance in the leafcutting bee (Megachile rotundata (Fabr)). I. Challenge of selected lines. Apidologie 21, 209-219

Stephen WP, Undurraga JM (1976) Xradiography, an analytical tool in population studies of the leafcutter bee, Megachile pacifica. J Apic Res 15, 81-87 